\title{
MAQASID AL-SHARIAH BASED MEASUREMENT INDEX FOR SOCIO-ECONOMIC DEVELOPMENT: A CASE STUDY IN NORTH SUMATRA INDONESIA
}

\author{
Dr. Indra Jaya,
}

Indonesia.

\begin{abstract}
This study develops an index towards the creation of a socio-economic development index based on Maqasid al-Shariah with a special case of North Sumatra Indonesia. The aim of this study is to find indicators and determinant factors of success and lack of success of the implementation of the Maqasid al-Shariah in socio-economic development in North Sumatra Indonesia; to measure the attitude of society in their participation of the socio-economic development based on Maqasid alSyariah; and to design a suitable modelof a socio-economic development measurement index based on Maqasid al-Shariah.Using Structural Equation Modeling (SEM) and Path Analysis Statistical Method developed by Karl Joreskog and Dag Sorbom, involving 794 respondents from different sectors of society and related institutions such as conventional banks claiming to apply sharia principles, religious institutions in society, religious educational institutions at primary, and secondary and tertiary levels in eight regencies and cities in North Sumatra, the result of the study showed that, in order, the variable of societal religious education quality, health quality, interreligious relationship quality, and educational level quality are determining indicators to ensure the success of socio-economic development based on maqashid al-sharia in North Sumatra, along with 'maintaining life'.
\end{abstract}

Keywords: North Sumatra, socio-economic development, maqasid al-sharia index. 


\section{INTRODUCTION:}

North Sumatra is a major province in Indonesia. Often called a miniature of Indonesia, people from a variety of tribes, religion and culture live and co-exist in North Sumatra. Almost all tribes and ethnicities in Indonesia such as (1) Malay, (2) Batak (which is further divided into Toba, Mandailing, Simalungun, Karo, and Dairi), (3) Nias, (4) Javanese, (5) Minang, (6) Sunda, (7) Aceh, and (8) immigrant ethnic such as Chinese, Indian and religious adherents (such as the Muslims (majority) and the minority Christian Protestants, Catholics, Hindus serta Buddhists) found in North Sumatra (Indonesian Central Statistic Bureau, 2014).

Therefore, the diversity of ethnic, social, economic, religious and culture on one hand can bring a positive result to the high rate of dynamic, competitive, and social creativity. The nature of dynamic, competitive and creative environment is a great potential that can be developed and used as the basis for the development of maqasid alshariah for Muslims in North Sumatra. However, behind that, diversity can also lead to conflicts, if the community of Muslims along with stakeholders were mistaken in laying position. Then this situation will be a factor of disintegration and endanger the realization of harmonious development in the field of social economy that is based on maqasid al-shariah in North Sumatra.

This research aims to: 1). Knowing the picture of the living conditions of the people of North Sumatra; 2). Reveal the determinant indicators maqasid al-shariah in North Sumatra. 3). Finding a fit model of social and economic life based on maqasid al-shariah in North Sumatra.

\section{LITERATURE REVIEW:}

Over the decades, development has taken a much wider connotation compared to discuss at first. From simple growth models of 1950s and 1960s, there has been a growing acceptance that development has to be holistic. In 1999, the World Bank introduced the Comprehensive Development Framework (CDF) which very clearly stated that development should be viewed as a multi-dimensional process that covered social, structural, human, governance, environmental, economic and financial spheres if it was to be seen as a meaningful and sustainable process. This kind of holistic approach is congruent with the Islamic viewpoint on development. Islam encourages economic development that also establishes social justice and the well-being of human beings.

Despite the recognition of the importance of religion in the multi-dimensional approach to development, the conceptual and theoretical frameworks of this alternative development model is still lacking. There is an urgent need for Muslim countries to develop this alternative model that represents a more holistic and inclusive concept of development that integrates the physical/material, intellectual and spiritual dimensions of human beings.

Islam encourages economic development that also establishes social justice that concerns itself with the wellbeing of human beings. Central to the Islamic view on development is the higher purposes of the Shari 'ah or Maqasid al-Shari 'ah that has stated three fundamental goals, i.e., educating the individual, establishing justice and ensuring the well-being or Maslahah of all. The Shari'ah is much more than just law, it is a total guidance and constitutes values, norms and general guidelines for ensuring total well-being of man. In trying to discuss Islamic economics, the Maqasid al-Shari 'ah provides a potentially comprehensive framework that can be used to measure development as represented by the concept of Maslahah.

The major focus of past literature on al-Maqasid was on developing the theory, and most of the discussions centered on its legal dimensions. The pioneering works emanated from scholars such as, Al-Juwayni (1979), AlGhazali (1901), Al-Shatibi (n.d), Ibn 'Ashur (1998) and Ibn Taymiyyah (al-Raysuni, 1992). Recently, the application of al-Maqasid in various disciplines including economics and finance has been gaining prominence. Among the leading economists who have written on the subject, to mention a few are Chapra (1985 and 2000), Siddiqi (2000), Ahmad (2000), Atiyah (2008), Hasan (2004) and Al-Najjar (2008). Their works however, relate al-Maqasid to the discipline of economics in a broad theoretical framework. Chapra (2008) came up with a model of human development from a Maqasid perspective. However, the study is still at a philosophical and theoretical level that needs to be cascaded at the operational level. Therefore, there is a need for extending the application of al-Maqasid to comprehensive development at macro level both in theory and application.

Several indices have been developed as variations or possible alternatives to the more commonly used HDI to measure human well-being in the process of development, such as the Quality of Life Index, the Happiness Index and the less known Meaning of Life Index, very few have attempted to integrate the religious aspect of development that reflects spiritual well-being which has been recognized as an important component in the construction of the indices. The Ethics-Augmented Human Development Index (E-HDI) by Dar (2004), the Islamic Human Development Index (I-HDI) by Anto (2009) and the Islamicity Index (I2)by Rehman and Askari (2010) are three of such attempts.

International Refereed Research Journal a www.researchersworld.com a Vol.- VII, Issue - 4(1), Oct. 2016 [129] 
The E-HDI is based on Maqasid al-Shari'ah and it conceptualizes social change and development for all countries. It encompasses more explicitly the ethical concerns in measuring development by incorporating freedom, faith, environmental concerns and family values in the HDI. However, the ranking of countries in the study is based on the ordinal measure using the Borda Rule instead of on the actual values of E-HDI computed for all countries. Hence, there is a need to develop a comprehensive development index based on Maqasid alShari' ah that can actually be computed for the ranking of countries' level of development. Anto (2009) attempts to develop such an index with the I-HDI. The index is comprised of what is termed as Material Welfare Index (MWI) and Non-material Welfare Index (NWI) representing the five basic needs in Maqasid al-Shari'ah. In addition, it also includes the Freedom Index and the Environment Index.

The Islamicity Index (I2) was developed to measure the degree of "Islamicity" of Islamic and non-Islamic countries based on the principles of Islam, aims at finding out whether or not Islam is an agent that enhances human development and its economic performance. It uses four sub-indices namely the Economic Islamicity Index $\left(\mathrm{EI}^{2}\right)$, the Legal and Governance Islamicity Index $\left(\mathrm{LGI}^{2}\right)$, the Human and Political Rights Islamicity Index $\left(\mathrm{HPI}^{2}\right)$, and the International Relations Islamicity Index $\left(\mathrm{IRI}^{2}\right)$. These indices in a nutshell, measures government's adherence to Islamic principles in their economics; legal integrity and governance environment; degree of civil and political rights; and relationship with the global community in regard to several keys areas of environmental contribution, globalization, military engagement, and overall country risk (Rehman and Askari, 2010). In this index, Islamic economic, financial, political, legal, and social principles were represented by 67 proxies which are the standard practice of good governance and good economics applicable to all countries regardless of their religious orientation. However, the Islamicity Index basically uses existing indicators which represent universal values, and therefore it is not really based on Maqasid al-Shari'ah.

In view of the limitations of existing development indices proposed, this study is aimed at the construction of an integrated Islamic development framework that culminates in the creation as a new and more comprehensive alternative to the existing measures of living standards and human well-being. and is proposed to be an integrated and a more holistic alternative to the existing measures of living standards and human well-being in North Sumatera.

\section{Socio-Economic Development of Maqasid al-Shariah:}

In general, it can be understood that the development is social change, whereas the social change is not always synonymous with development. In the context of this, development is the planned changes which are deliberate and desirable to achieve certain goals. Qorib (1977) describes in language that maqashid shari'a consists of two words such as 'maqdsid' and 'Syari'ah'. Maqashid means 'deliberate' or 'destination' whereas 'maqashid', a form jama 'of Maqsud derived from the syllables meaning Qashada want or mean, mean things maqashid things desired and intended. Further explained, 'Shariah' literally means 'The road to the source of life'. Portes (1976) defines development (development) as the transformation of economic, social and cultural. In a further development, the development can be divided into economic development and social development, as proposed by Blakely (2000). Economic development with regard to investment, increased absorption of the workforce, and increase workers' wages. In the view of endogenous development, economic development can be understood as a process through which local governments in collaboration with community groups and the private sector in managing the available resources to create jobs and stimulate economic activity (Blakely, 2000). Social development with regard to the development of society as a whole, which includes economic, political, cultural, legal, institutional, health, education and other social dimensions. It includes the empowerment of the private sector and civil society as well and the process of participatory and accountable political, economic and social infrastructure, including social services are adequate and satisfying. Based on the previous description, while the restriction is meant by social economi development of sharia in this study there: a planned and deliberate changes in the field of social economy is based on Shari'a as set out in Islam for the purpose eningkatan quality of life and welfare of the community (Ummah)

\section{METHODOLOGY:}

Using Structural Equation Modeling (SEM) and Path Analysis Statistical Method developed by Karl Joreskog and Dag Sorbom, an analysis of 794 respondents from different sectors of society and related institutions such as conventional banks claiming to apply sharia principles, all religious institutions in society, religious educational institutions at primary, and secondary and tertiary levels in eight regencies and cities in North Sumatra were conducted.The model framework used in this study is as follows:

International Refereed Research Journal a www.researchersworld.com a Vol.- VII, Issue - 4(1), Oct. 2016 [130] 


\section{Figure 1: Model Framework}

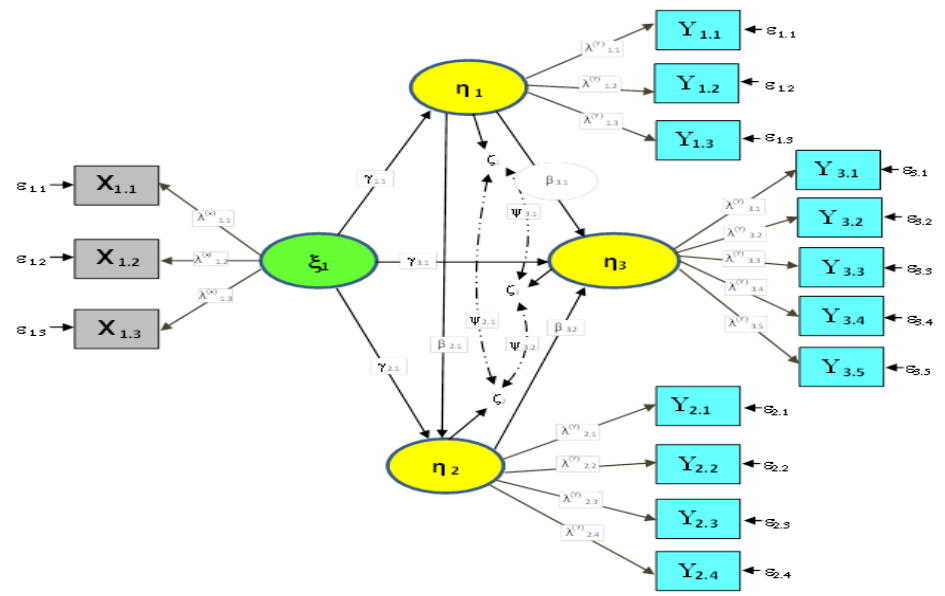

Each variable could be explained as follows:

(1) Socio-economic development based on Maqashid al-Shariah( $\left(Y_{3}\right)$; observed variables:
(a) maintaining religion $\left(\mathrm{Y}_{3.1}\right)$
(b) maintaining life $\left(\mathrm{Y}_{3.2}\right)$
(c) maintaining reason $\left(\mathrm{Y}_{3.3}\right)$
(d) maintaining progeny $\left(\mathrm{Y}_{3.4}\right)$
(e) maintainingwealth $\left(\mathrm{Y}_{3.5}\right)$

(2) Non-physical life quality $\left(\mathbf{Y}_{2}\right)$;observed variables:
(a) quality of character in adhering to Islamic shariah $\left(\mathrm{Y}_{2.1}\right)$
(b) quality of harmony with surrounding environment $\left(\mathrm{Y}_{2.2}\right)$
(c) quality of inter-religious relationship $\left(\mathrm{Y}_{2.3}\right)$
(d) quality of obeyance to community leaders and Muslim scholars ( $\left.\mathrm{Y}_{2.4}\right)$

(3) Physical life quality $\left(Y_{1}\right)$; observed variables:
(a) economic quality $\left(\mathrm{Y}_{1.1}\right)$
(b) health quality $\left(\mathrm{Y}_{1.2}\right)$
(c) educational quality $\left(\mathrm{Y}_{1.3}\right)$

(4) Societal attitude towards Maqashid al-Shariahsocio-economic development $\left(\mathrm{X}_{1}\right)$; observed variables:

(a) quality of society's religious education $\left(\mathrm{X}_{1.1}\right)$

(b) institutionaldevelopment of zakat management agency $\left(\mathrm{X}_{1.2}\right)$

(c) institutionaldevelopment of Islamic Financial Institutions $\left(\mathrm{X}_{1.3}\right)$

\section{FINDINGS:}

The following output analysis are found:

Figure 2: Standardized Solution Output Analysis

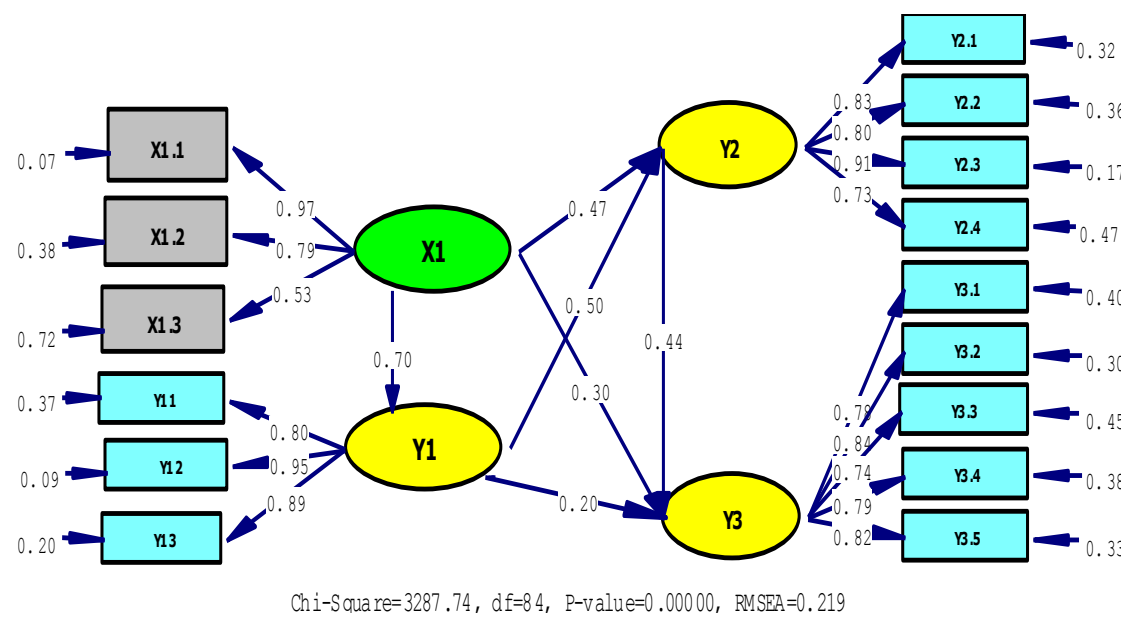




\section{Figure 3:T -Values Output Analysis}

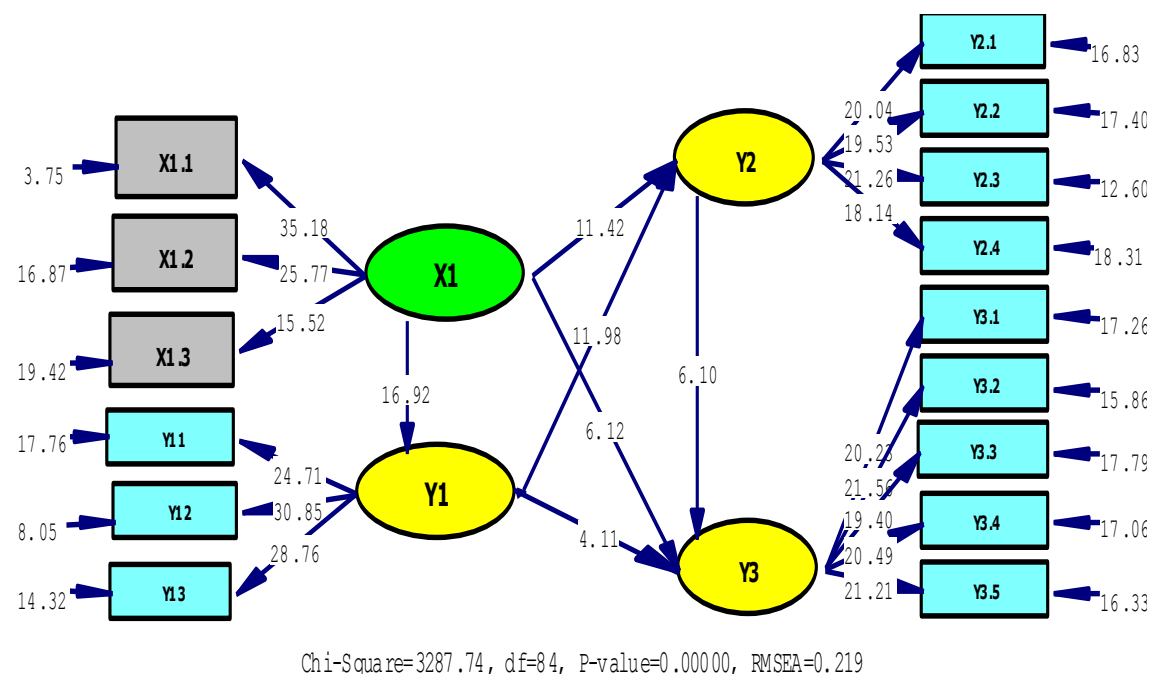

The standardized solutionoutput analysis in Figure 2 could explain the estimated influence of physical life quality $\left(\mathrm{Y}_{1}\right)$, non-physical life quality $\left(\mathrm{Y}_{2}\right)$, and societal attitude towards Maqashid al-Shariahsocio-economic development $\left(\mathrm{X}_{1}\right)$ on socio-economic development based on Maqashid al-Shariah( $\left.\mathrm{Y}_{3}\right)$. It could also explain how determining (through the determinant index coefficient) are the observed variables $\left(\mathrm{X}_{1.1}\right.$ to $\left.Y_{3.5}\right)$ on each $\mathrm{Y}_{1}$, $\mathrm{Y}_{2}, \mathrm{X}_{1}$ and $\mathrm{Y}_{3}$. The T-Values output analysis in Figure 3 could explain the level of significance of each variables coefficient produced by the standardized solution model.

The following tables are divided into three sections to summarize the result of analysis:

(1) The direct, indirect and total contribution given by each variable of physical life quality $\left(\mathrm{Y}_{1}\right)$, non-physical life quality $\left(\mathrm{Y}_{2}\right)$, and societal attitude towards maqashid al-shariahsocio-economic development $\left(\mathrm{X}_{1}\right)$ on the socio-economic development based on maqashid al-shariah $\left(\mathrm{Y}_{3}\right)$

(2) The contribution of each indicators to each variable of $\mathrm{Y}_{1}, \mathrm{Y}_{2}$, and $\mathrm{x}_{1}$ on $\mathrm{Y}_{3}$

(3) The indicator which contributes to maqashid al-shariah socio-economic index.

Section (1):the direct, indirect and total contribution given by each variable of $p$ hysical life quality $\left(\mathrm{Y}_{1}\right)$, nonphysical life quality $\left(\mathrm{Y}_{2}\right)$, and societal attitude towards Maqashid al-Shariahsocio-economic development $\left(\mathrm{X}_{1}\right)$ on the socio-economic development based on Maqashid al-Shariah $\left(\mathrm{Y}_{3}\right)$.

Table 1A: Direct Contribution of Y1, Y2, and X1 on Y3

\begin{tabular}{|c|c|c|c|c|c|c|c|}
\hline \multirow{3}{*}{ No } & \multirow{3}{*}{ Variable } & \multicolumn{5}{|c|}{$\begin{array}{l}\text { Socio-economic development based on } \\
\text { Maqashid al-Shariah }\left(\mathrm{Y}_{3}\right)\end{array}$} & \multirow{3}{*}{ Note } \\
\hline & & \multicolumn{5}{|c|}{ Coefficient } & \\
\hline & & $\mathbf{r}$ & $\mathbf{r}^{2}$ & $\%$ & Sig. $\mathbf{P}$ & T-Values & \\
\hline 1 & Physical life quality $\left(\mathrm{Y}_{1}\right)$ & 0.20 & 0.040 & 4.00 & 0.04 & 4.11 & Significant \\
\hline 2 & Non-physical life quality $\left(\mathrm{Y}_{2}\right)$ & 0.44 & 0.194 & 19.36 & 0.07 & 6.10 & Significant \\
\hline 3 & Societal attitude $\left(\mathrm{X}_{1}\right)$ & 0.30 & 0.090 & 9.00 & 0.05 & 6.12 & Significant \\
\hline
\end{tabular}

Based on Table 1A above, it could be seen that the non-physical life quality (Y1) is a dominant factor to increase socio-economic development based on Maqashid al-Shariah (Y3) with contribution of 19.36\%. Societal attitude (XI) contributes 9\%while physical life quality (Y1) contributes 4\%. Contribution of all variables are $77 \%$ which is expressed with the structural equation $\mathrm{Y} 3=0.20 * \mathrm{Y} 1+0.44 * \mathrm{Y} 2+0.30 * \mathrm{X} 1$. Thus $23 \%$ contributions are based on other variables not examined in this study. 
Table 1B: Direct Contribution of X1, Y1 on Y2

\begin{tabular}{|c|l|c|c|c|c|c|c|}
\hline \multirow{2}{*}{ No } & \multirow{2}{*}{ Variable } & \multicolumn{4}{|c|}{ Non-physical Life Quality $\left(\mathbf{Y}_{2}\right)$} & \multirow{2}{*}{ Note } \\
\cline { 3 - 7 } & & $\mathbf{r}$ & $\mathbf{r}^{2}$ & $\%$ & Sig. P & T-Values & \\
\hline 1 & Societal attitude $\left(\mathrm{X}_{1}\right)$ & 0.47 & 0.221 & 22.1 & 0.04 & 11.42 & \multirow{2}{*}{ Significant } \\
\hline 2 & Physical life quality $\left(\mathrm{Y}_{1}\right)$ & 0.50 & 0.25 & 25 & 0.04 & 11.98 & Significant \\
\hline
\end{tabular}

Table 1C: Direct Contribution Of X1 On Y1

\begin{tabular}{|c|c|c|c|c|c|c|c|}
\hline \multirow{3}{*}{ No } & \multirow{3}{*}{ Variable } & \multicolumn{5}{|c|}{ Physical Quality $\left(\mathrm{Y}_{1}\right)$} & \multirow{3}{*}{ Note } \\
\hline & & \multicolumn{5}{|c|}{ Coefficient } & \\
\hline & & $\mathbf{r}$ & $\mathbf{r}^{2}$ & $\%$ & Sig. P & $\mathbf{T}-$ Values & \\
\hline 1 & Societal attitude $\left(\mathrm{X}_{1}\right)$ & 0.70 & 0.49 & 49 & 0.04 & 16.92 & Significant \\
\hline
\end{tabular}

Based on Table $1 B$ and Table 1C above, it could be seen that the direct contribution of societal attitude (X1) on non-physical life quality (Y2) is $22.1 \%$ and the direct contribution of physical life quality (Y1) on non-physical life quality (Y2) is $25 \%$. Both variables contributes $81 \%$ which is expressed with sub-structural equation of $\mathrm{Y} 2$ $=0.50 * \mathrm{Y} 1+0.47 * \mathrm{X} 1$. Hence $19 \%$ contribution are based on variables not examined on this study. In the meantime, the direct contribution of societal attitude (XI) on physical quality (Y1) is $49 \%$.

Table 1D: Indirect and Total Contribution of X1 on Y2 and Y3; and of Y1 on Y3

\begin{tabular}{|c|c|c|c|c|c|c|c|c|c|}
\hline Variable & \multirow{2}{*}{ Process Analysis } & \multicolumn{4}{|c|}{ Indirect Contribution } & \multicolumn{4}{|c|}{ Total Contribution } \\
\hline \multirow{3}{*}{$\begin{array}{l}\text { Indirect and total } \\
\text { contribution fo societal } \\
\text { attitude }\left(\mathrm{X}_{1}\right)\end{array}$} & & $\mathbf{r}$ & $\mathbf{r}^{2}$ & $\%$ & T-val & $\mathbf{r}$ & $\mathbf{r}^{2}$ & $\%$ & T-val \\
\hline & $\begin{array}{l}\text { Non-physical life } \\
\text { quality }\left(\mathrm{Y}_{2}\right)\end{array}$ & 0,35 & 0,123 & 12,25 & 11,20 & 0,83 & 0,69 & 68,89 & 16,25 \\
\hline & $\begin{array}{l}\text { Socio-economic } \\
\text { development based } \\
\text { on maqashid al- } \\
\text { shariah }\left(\mathrm{Y}_{3}\right)\end{array}$ & 0.50 & 0.25 & $25 \%$ & 10.21 & 0.80 & 0.64 & 64.00 & 16.94 \\
\hline $\begin{array}{l}\text { Indirect and total } \\
\text { contribution of } \\
\text { physical quality }\left(\mathrm{Y}_{1}\right)\end{array}$ & $\begin{array}{l}\text { Socio-economic } \\
\text { development based } \\
\text { on maqashid al- } \\
\text { shariah }\left(\mathrm{Y}_{3}\right)\end{array}$ & 0.22 & 0.048 & 48.5 & 5.52 & 0.41 & 0.17 & 16.81 & 9.87 \\
\hline
\end{tabular}

In addition to direct contribution, indirect contribution and total contribution as could be seen in Table 1D below could be explained as follows:

(a) Indirect contribution of societal attitude variable on non-physical life quality is as much as $12.25 \%$ and indirect contribution of societal attitude variable on socio-economic development based on maqashid alshariahis as much as $25 \%$. Indirect contribution of physical life quality variable on socio-economic development based on maqashid al-shariah is as much as $48.5 \%$

(b) Total contribution of societal attitude variable on non-physical life quality is as much as $68,89 \%$, and total contribution of societal attitude on socio-economic development based on maqashid al-shariah is $64 \%$. Total contribution of physical quality variable on socio-economic development based on maqasid al-shariah is $16.81 \%$.

Section (2): the contribution of each indicators to each variable of $Y_{1}, Y_{2}$, and $X_{1}$ on $Y_{3}$. 
Table 2A: Contribution of Indicators Y3.1 To Y3.5 on Y3

\begin{tabular}{|c|l|c|c|c|c|c|c|}
\hline \multirow{2}{*}{ No } & \multirow{2}{*}{ Variables } & \multicolumn{5}{|c|}{$\begin{array}{c}\text { Socio-Economic Development based on } \\
\text { Maqashid al-Shariah }\left(\mathbf{Y}_{\mathbf{3}}\right)\end{array}$} & \multirow{2}{*}{ Note } \\
\cline { 3 - 8 } & & \multicolumn{5}{c|}{ Coefficient } \\
\cline { 3 - 8 } & & $\mathbf{r}$ & $\mathbf{r}^{\mathbf{2}}$ & \% & Sig. P & T-Values & \\
\hline 1 & Maintaining religion $\left(\mathrm{Y}_{3.1}\right)$ & 0.78 & 0.6084 & 60.84 & 0.12 & 20.23 & Significant \\
\hline 2 & Maintaining life $\left(\mathrm{Y}_{3.2}\right)$ & 0.84 & 0.7056 & 70.56 & 0.13 & 21.56 & Significant \\
\hline 3 & Maintaining reason $\left(\mathrm{Y}_{3.3}\right)$ & 0.74 & 0.5476 & 54.76 & 0.10 & 19.40 & Significant \\
\hline 4 & Maintaining progeny $\left(\mathrm{Y}_{3.4}\right)$ & 0.79 & 0.6241 & 62.41 & 0.10 & 20.49 & Significant \\
\hline 5 & Maintaining wealth $\left(\mathrm{Y}_{3.5}\right)$ & 0.82 & 0.6724 & 67.24 & 0.09 & 21.21 & Significant \\
\hline
\end{tabular}

As could be seen in Table 2A above, the contribution of indicators Y3.1 to Y3.5 on Y3 could be explained as follows: maintaining religion contributes as much as $60.84 \%$, maintaining life as much as $70.56 \%$, maintaining reason as much as $54.76 \%$, maintaining progeny as much as $62.41 \%$ and maintaining wealth as much as $67.24 \%$. All contributions are significant. It could be seen that the highest contribution is given by the indicator maintaining life. As such maintaining life is the main determining indicator that contributes to socio-economic development based on maqashid al-shariah.

Table 2B: Contributions Of Indicators Y2.1 To Y2.4 On Y2

\begin{tabular}{|c|c|c|c|c|c|c|c|}
\hline \multirow{3}{*}{ No } & \multirow{3}{*}{ Variables } & \multicolumn{5}{|c|}{ Non-physical life quality $\left(\mathrm{Y}_{2}\right)$} & \multirow{3}{*}{ Note } \\
\hline & & \multicolumn{5}{|c|}{ Coefficient } & \\
\hline & & $\mathbf{r}$ & $\mathbf{r}^{2}$ & $\%$ & Sig $\mathbf{P}$ & T-Val & \\
\hline 1 & Quality of character $\left(\mathrm{Y}_{2.1}\right)$ & 0.83 & 0.6889 & 68.89 & 0.32 & 20.04 & Significant \\
\hline 2 & Quality of harmony $\left(\mathrm{Y}_{2.2}\right)$ & 0.80 & 0.6400 & 64.00 & 0.15 & 19.53 & Significant \\
\hline 3 & $\begin{array}{l}\text { Quality of inter-religious } \\
\text { relationship }\left(\mathrm{Y}_{2.3}\right)\end{array}$ & 0.91 & 0.8281 & 82.81 & 0.29 & 21.26 & Significant \\
\hline 4 & Quality of obeyance $\left(\mathrm{Y}_{2.4}\right)$ & 0.73 & 0.5329 & 53.29 & 0.17 & 18.14 & Significant \\
\hline
\end{tabular}

As could be seen on Table 2B above, the contribution of indicators Y2.1 to Y2.4 on Y2 could be explained as follows: quality of character in adhering to Islamic shariah contributes as much as $68.89 \%$, quality of harmony with surrounding environment contributes as much as $64 \%$, quality of inter-religious relationship contributes as much as $82.81 \%$, and quality of obeyance to community leaders and Muslim scholars as much as $53.29 \%$. All indicator contributions are significant. As the highest contribution is given by the indicator of inter-religious relationship quality, it is the main determining indicator of non-physical life quality.

Table 2C: Contributions of Indicators Y1.1 To Y1.3 on Y1

\begin{tabular}{|c|c|c|c|c|c|c|c|}
\hline \multirow{3}{*}{ No } & \multirow{3}{*}{ Variable } & \multicolumn{5}{|c|}{ Physical life quality $\left(\mathbf{Y}_{1}\right)$} & \multirow{3}{*}{ Note } \\
\hline & & \multicolumn{5}{|c|}{ Coefficient } & \\
\hline & & $\mathbf{r}$ & $\mathbf{r}^{2}$ & $\%$ & Sig. $\mathbf{P}$ & T-Values & \\
\hline 1 & Economic quality $\left(\mathrm{Y}_{1.1}\right)$ & 0.80 & 0.64 & 64 & 0.39 & 24.71 & Significant \\
\hline 2 & Health quality $\left(\mathrm{Y}_{1.2}\right)$ & 0.95 & 0.90 & 90 & 0.36 & 30.81 & Significant \\
\hline 3 & Educational quality $\left(\mathrm{Y}_{1.3}\right)$ & 0.89 & 0.79 & 79 & 0.28 & 28.76 & Significant \\
\hline
\end{tabular}

As could be seen from Table $2 \mathrm{C}$ above, the contribution of indicators $\mathrm{Y} 1.1$ to $\mathrm{Y} 1.3$ on $\mathrm{Y} 2$ could be explained as follows: economic quality contributes as much as $64 \%$, health quality contributes as much as $90.25 \%$, and educational quality contributes as much as $79.21 \%$. All contributions of indicators are significant. Health quality is the main determining indicator of physical life quality as it provides the largest contribution. 
Table 2D: Contributions Of Indicators X1.1 To X1.2 On X1

\begin{tabular}{|c|l|c|c|c|c|c|c|}
\hline \multirow{2}{*}{ No } & \multirow{2}{*}{ Variable } & \multicolumn{4}{c|}{ Societal attitude (X1) } & \multirow{2}{*}{ Note } \\
\cline { 3 - 9 } & & $\mathbf{r}$ & $\mathbf{r}^{\mathbf{2}}$ & $\mathbf{\%}$ & Sig. P & T-Values & \\
\hline 1 & Quality of societal religious education $\left(\mathrm{X}_{1.1}\right)$ & 0.97 & 0.94 & 94.09 & 0.15 & 35.18 & Significant \\
\hline 2 & Development of Zakat Agency $\left(\mathrm{X}_{1.2}\right)$ & 0.79 & 0.62 & 62.41 & 0.08 & 25.77 & Significant \\
\hline 3 & Development of Islamic Financial Institution $\left(\mathrm{X}_{1.2}\right)$ & 0.53 & 0.28 & 28.09 & 0.08 & 15.57 & Significant \\
\hline
\end{tabular}

As could be seen from Table 2D above, the contribution of each indicator X1.1 to X1.2 on X1 could be explained as follows: quality of societal religious education contributes as much as $94.09 \%$, development of zakat agency contributes as much as $62,41 \%$ and development of Islamic Financial Institution contributes as much as $28,09 \%$. All indicator contributions are significant. The main determining indicator is quality of societal religious education as it provides the largest contribution.

Section (3): the indicators which contributes to maqashid al-shariah socio-economic index.

Based on Section (1) and Section (2), the indicators which contributes to the maqashid al-shariah socioeconomic index could be seen as follows in Table 3.

Table 3: Contributive Indicators To Maqashid Al-Shariah Socio-Economic Index

\begin{tabular}{|c|c|c|c|}
\hline \multicolumn{2}{|r|}{ Indicators } & \multicolumn{2}{|c|}{ Index } \\
\hline 1 & Societal religious educationquality & $94.09 \%$ & \\
\hline 2 & Health quality & $90.25 \%$ & \\
\hline 3 & Inter-religious relationship quality & $82.81 \%$ & $\overline{\mathscr{D}}$ \\
\hline 4 & Educational quality & $79.21 \%$ & $\Xi$ \\
\hline 5 & Maintaining life & $70.56 \%$ & 苞 \\
\hline 6 & Character quality & $68.89 \%$ & है \\
\hline 7 & Maintaining wealth & $67.24 \%$ & $\frac{0}{0} \cdot \Xi$ \\
\hline 8 & Economic quality & $64.00 \%$ & 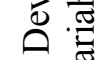 \\
\hline 9 & Harmony with surrounding environment & $64.00 \%$ & $\cdot \frac{\tilde{q}}{\pi}$ \\
\hline 10 & Development of zakat agency & $62.41 \%$ & \\
\hline 11 & Maintaining progeny & $62.41 \%$ & $8: 0$ \\
\hline 12 & Maintaining religion & $60.84 \%$ &.$\frac{\pi}{0}$ \\
\hline 13 & Maintaining reason & $54.76 \%$ & $\delta_{0}^{0 \pi}$ \\
\hline 14 & Obeyance to leaders/scholar & $53.29 \%$ & ธี \\
\hline 15 & Development of Islamic Financial Institution & $28.09 \%$ & \\
\hline
\end{tabular}

\section{DISCUSSION AND CONCLUSION:}

Based on the index, the primary indicators and thus determinant factors of success of maqasid al-shariah for socioeconomic development of North Sumatra are societal religious education quality, health quality, inter-religious relationship quality, educational quality, and maintaining life. The lack of development of these indicators would cause the failure of socio-economic development based on maqasid al-shariah in North Sumatra.

The secondary indicators and thus dominant factors are character quality, maintaining wealth, economic quality, harmony with surrounding environment quality, and development of zakat agency. These indicators need to be increased if socio-economic development based on maqasid al-shariah in North Sumatra is to be improved.

The tertiary indicators and thus supporting factors are maintaining progeny, maintaining religion, maintaining reason, obeyance to leaders/scholar, and development of Islamic Financial Institution. These indicators need much improvent for a socio-economic development based on maqashid al-shariah in North Sumatra.

The model for socio-economic development based on maqasid al-shariah in North Sumatra could thus be found as follows: 
Figure 4: Model of Socio-Economic Development Based on Maqasid Al-Shariah in North Sumatra

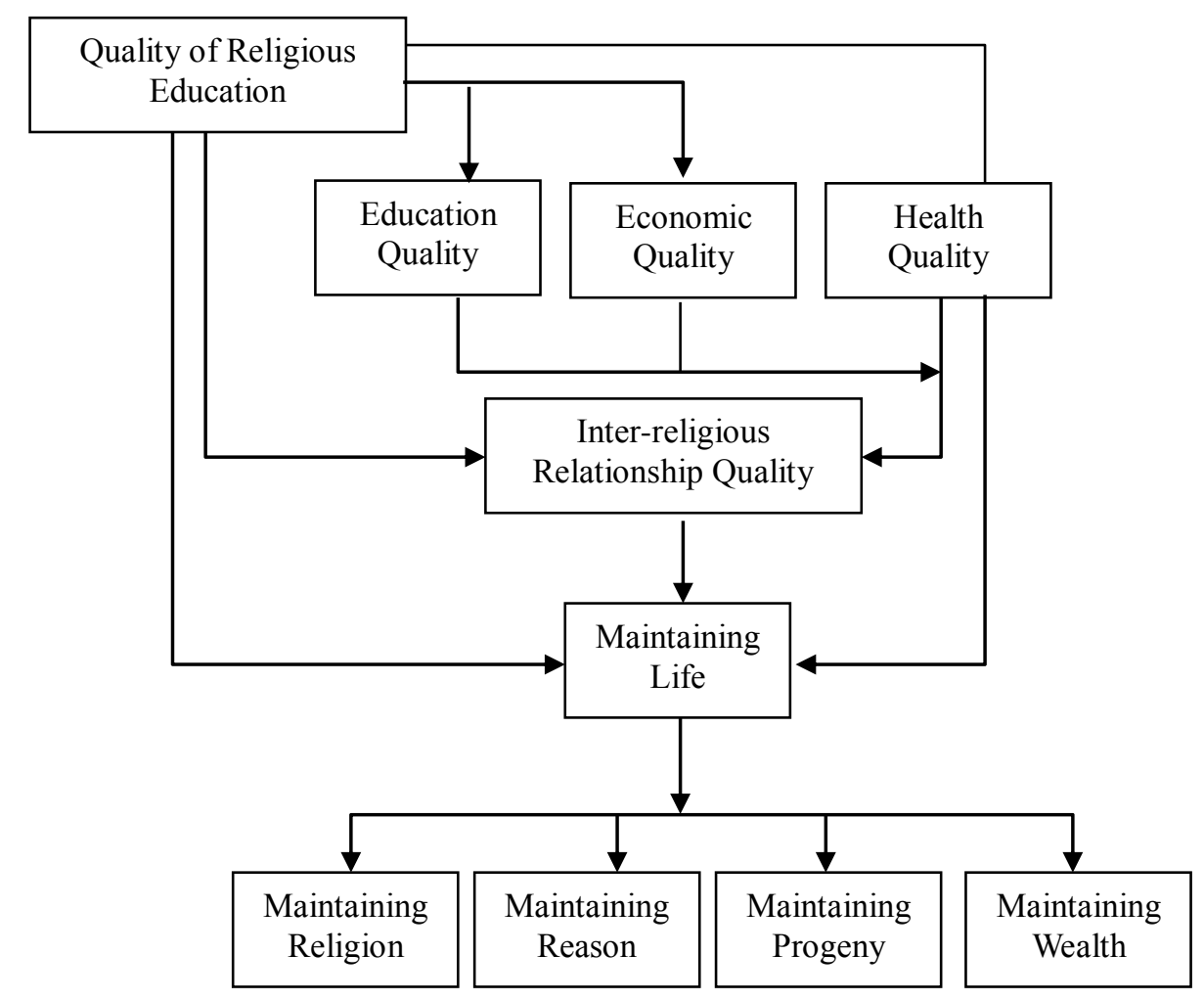

\section{REFERENCES:}

[1] Al-Ghazali, Abu Hamid.(1901). Al-mustasfa min 'ilm al-usul. (1st Ed.). Al-Matba'ah al-Amiriyyah, Egypt.

[2] Al-Shatibi, Abu Ishaq (2004). Al-muwafaqat fi usul al-Shari'ah. Dar al-Kutub al-'Ilmiyah, Beirut.

[3] Amin, RuzitaMohdet. al., The Integrated Development Index (I-Dex): A New Comprehensive Approach To Measuring Human Development, Paper presented at 9th International Conference on Islamic Economics and Finance: Growth, Equity and Stability: An Islamic Perspective. Istanbul, Turkey. 9-10 September 2013.

[4] Auda, Jasser. (2008). Maqasid al-Shari'ah as philosophy of Islamic law, a system approach. International Institute of Islamic Law, London.

[5] Auda, Jasser. (2010). Maqasid al-Shari'ah as philosophy of law: a system approach. Kuala Lumpur: ISTAC.

[6] Blakely, E.D. dan Ted K. Bradshaw. (2000). Planning Local Economic Development: Theory and Practice. Thousand Oaks, CA: Sage.

[7] Hair, J. F., Anderson, R. E., Tatham, R. L., \& Black, W. C. (1998). Multivariate Data Analysis. New Jersey: Prentice Hall

[8] Hulland, J., Chow, W. H., \& Lam, S. (1996). Use of causal models in marketing research: A review. International Journal of Research in Marketing 13: 181-197.

[9] Joreskog, Karl;Sorbom, Dag. (1999). Interactive LISREL. User's Guide, Scientific Software International, Inc. New Jersey. USA. 